\title{
POLA PENGELUARAN KONSUMSI RUMAHTANGGA TANI PENERIMA BANTUAN MODAL PRODUKSI TERNAK SAPI DI KECAMATAN TOMPASO BARAT KABUPATEN MINAHASA
}

\author{
Christian Tangkere, Sintya J.K. Umboh*, Merry A.V. Manese, Nansi M. Santa \\ Fakultas Peternakan, Universitas Sam Ratulangi Manado, 95115
}

\begin{abstract}
ABSTRAK
Rumahtangga tani adalah unit ekonomi yang memiliki keputusan produksi dan konsumsi. Bantuan modal produksi ternak yang diperoleh rumahtangga tani dialokasikan penggunaannya dalam konteks konsumsi rumahtangga untuk memaksimumkan utilitas / kepuasan. Penelitian ini bertujuan untuk menganalisis pola pengeluaran konsumsi rumahtangga tani penerima bantuan modal produksi ternak. Penelitian ini menggunakan metode survei dengan analisis deskriptif dan kuantitatif.. Rumahtangga responden adalah rumahtangga tani penerima bantuan modal yang telah menjual sapi bantuan. Pola pengeluaran konsumsi rumahtangga tani penerima bantuan modal produksi ternak di Kecamatan Tompaso Barat dibagi atas: pengeluaran konsumsi pangan dan non pangan. Pengeluaran konsumsi pangan dibedakan antara pengeluaran konsumsi pangan yang dibeli dan tidak dibeli. Hasil penelitian menunjukkan bahwa dari ketiga alokasi pengeluaran konsumsi tersebut diketahui bahwa alokasi pengeluaran konsumsi pangan yang dibeli terbesar pada pengeluaran untuk ikan yakni sebesar 28,69 persen, nilai pengeluaran konsumsi pangan yang tidak dibeli pada bumbu makanan (29.94 \%), dan alokasi pengeluaran konsumsi non pangan pada pengeluaran untuk pakaian, alas kaki, dan penutup kepala $(27.83 \%)$.
\end{abstract}

\section{Kata Kunci :Pengeluaran, Konsumsi, Rumahtangga}

*Korespondensi(correspondingauthor): E-mail: sintyajkumboh@yahoo.co.id

\begin{abstract}
THE PATTERN OF HOUSEHOLD FARMERS CONSUMPTION EXPENDITURE OF BENEFICIARIES OF CAPITAL ASSISTANCE FOR CATTLE PRODUCTION IN THE WESTERN TOMPASO DISTRICT OF MINAHASA REGENCY. Household
\end{abstract} farmers are one of the economic units that have a relationship with production and consumption decisions. Assistance of livestock production capital obtained by household farmers allocated its use in the context of household consumption to maximize the utility or satisfaction of the household. This research aims to analyze the pattern of consumption expenditure on farmers households as a recipient of production capital assistance for livestock. The study used descriptive and quantitative analysis. The respondent of this research which is household farmer's as one of the recipients of capital assistance that has been selling cows. Patern of household consumption expenditure by farmers as beneficiaries of capital assistance in the district of West Tompaso divided into: Food and Non-food consumption. Expenditure of food consumption differentiated two types which are expenditure of food consumption purchased and not purchased. The results showed that out of all three allocation of consumption expenditure is known that the allocation of food consumption expenditure of household farmers is divided in to the first; the largest purchased for fish production is 28.69 percent, second; the value expenditure of food consumption not purchased in food seasonings (29.94\%), and the last one is the allocation of non-food consumption 
expenditure were on clothing, footwear, and headgear $(27.83 \%$.)

\section{Keywords :Expenditure, consumption, households}

\section{PENDAHULUAN}

Tujuan pemberian bantuan modal produksi ternak oleh pemerintah dan lembaga lain pada hakekatnya untuk meningkatkan produksi ternak. Dengan Kmeningkatnya produksi diharapkan pendapatan rumahtangga tani juga meningkat. Kenyataannya rumahtangga tani dalam memutuskan dan mengalokasikan penggunaan modal tidak seluruhnya untuk kegiatan produksi seperti yang diinginkan pemerintah, tetapi juga digunakan untuk konsumsi dan investasi (deRosari et al., 2014). Manajemen likuiditas keuangan dari pengajuan peminjaman dan penggunaannya merupakan keputusan ekonomi rumahtangga yang menjaga resiko keuangan yang disebabkan oleh guncangan resiko bisnis (Gabriel and Baker 1980; Caillavet et al 1994). Hal ini terkait dengan eksistensi rumahtangga tani yang bertindak sebagai produsen sekaligus sebagai konsumen yang memaksimumkan kepuasan atau utilitas dan mendapatkan keuntungan atau profit dari kegiatan produksi usahataninya. Atau dengan kata lain, tidak ada rumahtangga tani yang bertindak sebagai produsen murni (pure producer) atau konsumen murni (pure consumer).Disamping itu, rumahtangga tani bertindak sebagai suatu organisasi ekonomi sehingga prinsip-prinsip likuiditas keuangan (liquidity of money) juga diterapkan. Bantuan modal produksi dapat digunakan untuk pengeluaran lainnya karena bantuan modal dianggap sebagai salah satu sumber untuk menjaga likuiditas keuangan rumahtangga (Elly et al., 2008; Obara et al.,2010).

Yasmeen et al.(2011) di Pakistan menyatakan bahwa pemberian bantuan modal oleh pemerintah setidak-tidaknya dapat meningkatkan standar hidup rumahtangga pertanian, terutama dalam 4 sektor, yakni kenaikan konsumsi listrik dan barang elektronik, peningkatan pendidikan anak, peningkatan penggunaan jasa transportasi dan asset, serta peningkatan konsumsi makanan dan kesehatan. Di Indonesia walaupun bantuan modal untuk sektor pertanian kecil, namun petani memiliki kearifan dalam menggunakan bantuan modal tersebut yang tidak untuk usaha tani semata.Modal tersebut juga di manfaatkan untuk kegiatan non usaha tani yang menunjang ekonomi rumahtangga.

Rumahtangga tani adalah unit ekonomi yang memiliki keputusan produksi dan konsumsi. Bantuan modal produksi ternak yang diperoleh rumahtangga tani dialokasikan 
penggunaannya dalam konteks konsumsi rumahtangga untuk memaksimumkan utilitas / kepuasan. Permasalahannya, sejauh mana pola konsumsi rumahtangga tani penerima bantuan modal produksi ternak di Kecamatan Tompaso Barat belum diketahui. Berdasarkan uraian diatas maka dirumuskan masalah : bagaimana pola konsumsi rumahtangga petani penerima bantuan modal produksi ternak di Kecamatan Tompaso Barat Kabupaten Minahasa.

\section{METODE PENELITIAN}

Penelitian ini dilaksanakan di Kecamatan Tompaso Barat Kabupaten Minahasa dengan pertimbangan ; (1) salah satu sentra populasi di Kabupaten Minahasa dan (2) salah satu kecamatan penerima bantuan modal produksi ternak sapi di Kabupaten Minahasa. Penelitian menggunakan metode survei. Pengumpulan data menggunakan teknik wawancara pada responden rumahtangga tani peternak sapi penerima bantuan modal dengan menggunakan kuesioner.

Pengumpulan datadilaksanakan pada Bulan September sampai Oktober 2018. Jenis data yang dikumpulkan data cross section dan data time series, dari sumber data primer dan data sekunder. Data primer (cross section setahun) diperoleh dari wawancara langsung dengan responden. Sedangkan data sekunder (time seriestahunan) diperoleh dari instansi yang terkait dengan penelitian ini serta data hasil penelitian yang dipublikasi (Sinaga. 2011)

Populasi rumahtangga peternak sapi adalah rumahtangga tani yang menerima bantuan modal untuk usaha ternak sapi. Penentuan rumahtangga responden adalah rumahtangga petani penerima bantuan modal yang telah menjual sapi bantuan.

\section{Definisi dan Pengukuran Variabel}

1. Rumahtangga adalah sekelompok orang yang mendiami sebagian atau seluruh bangunan, umumnya mereka tinggal disitu dan makan dari satu dapur.

2. Bantuan modal produksi ternak adalah bantuan ternak sapi yang diberikan pemerintah dengan maksud untuk meningkatkan kegiatan produksi ternak sapi. Untuk keperluan analisis, maka bantuan modal ini dinilai dalam nilai tertentu yang disesuaikan dengan nilai/harga pada saat bantuan modal diberikan (Rp/tahun).

3. Rumahtangga petani penerima bantuan modal produksi ternak adalah rumahtangga petani penerima bantuan modal produksi ternak sapi yang telah menjual sapi bantuan. 


\section{HASIL DAN PEMBAHASAN}

\section{Pengeluaran Konsumsi Rumahtangga Tani}

Rumahtangga dianggap sebagai suatu unit produksi dan konsumsi, maka tambahan modal produksi ternak sapi berpeluang dialokasikan untuk kegiatan produksi dan konsumsi. Tambahan modal ini akan menghasilkan lima alternatif proporsi pengalokasian, yakni (1) meningkatkan proporsi pengeluaran untuk produksi dan mengurangi proporsi pengeluaran konsumsi, (2) meningkatkan proporsi pengeluaran untuk produksi dan mempertahankan proporsi pengeluaran untuk konsumsi, (3) meningkatkan proporsi pengeluaran produksi dan konsumsi secara bersama-sama, dan (4) mempertahankan proporsi pengeluaran produksi dan meningkatkan proporsi pengeluaran konsumsi, dan mengurangi proporsi pengeluaran produksi dan meningkatkan proporsi pengeluaran konsumsi. Alternatif (1) dan alternatif (5) sangat jarang terjadi, sedangkan alternatif (2), (3), dan (4) sering terjadi. Tergantung keputusan rumahtangga masingmasing.Prinsip terpenting dalam pengelolaan pendapatan dan mengatur pengeluaran rumahtangga tani adalah untuk menjaga atau meningkatkan kesejahteraan hidupnya, sehingga dikatakan rumahtangga tani mempunyai kearifan tersendiri atau rumahtangga tani memiliki rasionalitas dalam pengelolaan pendapatan dan pengeluaran rumahtangganya.

Konsumsi pangan rumahtangga merupakan kebutuhan anggota rumahtangga terhadap pangan yang bertujuan untuk memantapkan ketahanan pangan di tingkat rumahtangga.Pola konsumsi ini dipengaruhi oleh pola makan sebagian besar penduduk, ketersediaan bahan pangan, dan tingkat pendapatan (Wantasen et al., 2012). Survei Sosial Ekonomi Nasional (SUSENAS) yang dilakukan oleh Badan Pusat Statistik (BPS), terdapat dua jenis pengelompokan pengeluaran konsumsi rumahtangga yaitu pengelompokan konsumsi makanan dan bukan makanan. Makanan merupakan salah satu barang yang paling sering dibutuhkan setiap orang, karena makanan sebagai sumber energi dalam melakukan aktifitas sehari-hari. Pola konsumsi khususnya konsumsi rumah tangga untuk makanan menjadi salah satu factor penentu tingkat kesehatan dan produktivitas rumahtangga. Aspek norma gizi memberikan standar minimum jumlah makanan yang dibutuhkan seorang individu agar dapat hidup sehat dan aktif beraktivitas dalam mewujudkan ketahanan pangan. Ketahanan pangan terwujud apabila seluruh penduduk mempunyai akses fisik dan ekonomi terhadap pangan 
untuk memenuhi kecukupan gizi (protein dan energi) sesuai kebutuhannya agar dapat menjalani kehidupan yang sehat dan produktif dari hari kehari. Mutu gizi makanan seseorang dapat diperbaiki dengan konsumsi pangan yang beragam.

Konsumsi pangan merupakan pembelanjaan masyarakat yang digunakan untuk memenuhi kebutuhan makanan, yang terdiri dari padi-padian, umbiumbian, sayur-sayuran, lauk pauk, buahbuahan, makanan dan minuman jadi, tembakau serta sirih. Sedangkan konsumsi bukan pangan adalah pembelanjaan untuk memenuhi kebutuhan selain pangan. Alokasi pengeluaran bukan makanan terdiri dari perumahan dan bahan bakar, aneka barang dan jasa, biaya pendidikan, biaya kesehatan, pakaian, alas kaki, barang-barang tahan lama, pajak dan premi asuransi, serta keperluan pesta dan upacara. Pembagian kelompok barang untuk makanan dan bukan makanan dapat dilihat pada Tabel 1

Tabel 1.Pembagian Kelompok Barang untuk Makanan dan Bukan Makanan.

\begin{tabular}{|c|c|c|c|}
\hline No. & Makanan & No & Bukan Makanan. \\
\hline 1. & Padi-padian/cereals & 1. & $\begin{array}{l}\text { Perumahan dan fasilitas rumahtangga } \\
\text { (Housing and household facilitles) }\end{array}$ \\
\hline 2. & Umbi-umbian/Tubers & 2. & Aneka barang dan jasa(Goods and services) \\
\hline 3. & Ikan/udang/cumi/kerang & 3. & $\begin{array}{l}\text { Pakaian, alas kaki dan tutup kepala } \\
\text { Clothing, footwear and heatgear }\end{array}$ \\
\hline 4. & $\begin{array}{l}\text { Fish/shrimp/common } \\
\text { squid/shells }\end{array}$ & 4. & $\begin{array}{l}\text { Barang tahan lama } \\
\text { Durable goods }\end{array}$ \\
\hline 5. & Daging/Meat & 5. & $\begin{array}{l}\text { Pajak, pungutan dan asuransi } \\
\text { Taxes and insurance }\end{array}$ \\
\hline 6. & Telur dan susu/eggs and milk & 6. & $\begin{array}{l}\text { Keperluan pesta dan upacara/kenduri } \\
\text { Parties and ceremonies }\end{array}$ \\
\hline 7. & Sayur-sayuran/vegetables & & \\
\hline 8. & Bumbu-bumbuan/Spices & & \\
\hline 9. & $\begin{array}{l}\text { Konsumsi lainnya } \\
\text { (Miscellaneous food items) }\end{array}$ & & \\
\hline 10. & $\begin{array}{l}\text { Makanan dan minuman jadi } \\
\text { (Prepared food and beverages) }\end{array}$ & & \\
\hline 11 & Rokok dan Tembakau & & \\
\hline
\end{tabular}


Tabel 2.Rata-rata Pengeluaran Konsumsi Pangan yang Dibeli di Kecamatan Tompaso Barat

\begin{tabular}{|c|c|c|c|}
\hline No. & Pengeluaran Pangan & $\begin{array}{c}\text { Rata-rata Pengeluaran } \\
(\mathrm{Rp})\end{array}$ & Persentase (\%) \\
\hline 1. & Ikan & 4.089333 & 28,69 \\
\hline 2. & Beras & 3.013533 & 26,67 \\
\hline 3. & Sayur & 1.871000 & 13,12 \\
\hline 4. & Bumbu Makanan & 1.781733 & 12,50 \\
\hline, 5 . & Umbi\&Buah & 1. 693017 & 11,88 \\
\hline 6. & lain-lain & 1.013533 & 7,11 \\
\hline & JUMLAH & 14.250 .250 & 100,00 \\
\hline
\end{tabular}

memiliki perbedaan keteraturan dalam pola pengeluaran secara umum.Pola pengeluaran ini bisa juga disebut pola konsumsi (sebab konsumsi merupakan suatu bentuk pengeluaran).Hukum Engel menyatakan bahwa semakin sejahtera seseorang maka semakin kecil persentase pendapatannya untuk membeli makanan. Dengan kata lain bahwa pola pengeluaran konsumsi bergeser dari pengeluaran untuk pangan ke pengeluaran bukan pangan. Semakin rendah pengeluaran konsumsi pangan dan semakin tinggi proporsi pengeluaran umtuk bukan pangan, maka tingkat kesejahteraan peternak semakin meningkat.Semakin tinggi tingkat sosial ekonomi peternak, semakin rendah proporsi pengeluaran konsumsi makanan pokok dan semakin tinggi proporsi pengeluaran bukan makanan.

Pola Pengeluaran Konsumsi Rumahtangga Tani Penerima Bantuan Modal Produksi Ternak di Kecamatan Tompaso Barat

Pengeluaran konsumsi rumahtangga adalah nilai belanja yang membeli berbagai jenis kebutuhannya (Pangan dan Non Pangan) dalam periode waktu tertentu. Berdasarkan hasil penelitian diketahui bahwa alokasi terbesar pengeluaran konsumsi pangan yang dibeli pada pengeluaran untuk ikan yakni sebesar 28,69 persen. Sedangkan pengeluaran terkecil pada konsumsi umbi dan buah (7.11 persen). Hal ini didukung oleh hasil penelitian Cahyaningsih (2008), Putranto dan Taufik (2014), dan Jayati et al. (2014) yang menyatakan bahwa kebutuhan ikan sebagai pangan sumber protein hewan.

Dilihat pada tabel 2. Rumahtangga berperilaku membeli pangan karena, (1) pendapatan rumahtangga tani merupakan hasil dari usahatani yang bukan untuk dikonsumsi langsung atau pendapatan dari usaha non pertanian, (2) produksi usahatani yang langsung dapat dikonsumsi namun jumlah produksi tidak mencukupi kebutuhan pangan rumahtangga, (3) strategi untuk menekan biaya penyimpanan, atau substitusi kualitas pangan yang dikonsumsi. Apabila 
rumahtangga terkategori dalam jenis (1) dan non usaha tani bersifat komersil. Rumahtangga tani yang terkategori dalam jenis (2) menggambarkan rumahtangga yang defisit pangan dari usahataninya, dan rumahtangga yang terkategori dalam jenis (3) adalah rumahtangga yang ketika produksi menjual hasilnya kemudian membeli pangan yang lebih baik atau membeli pangan yang kualitasnya kurang sehingga harganya lebih murah. Lebih lanjut untuk nilai konsumsi pangan yang tidak dibeli yakni konsumsi pangan yang disiapkan oleh usahatani sendiri.Hasil analisis diketahui bahwa nilai konsumsi tertinggi pada bumbu makanan (29.94\%) diikuti beras dan umbi masing-masing sebesar $23.62 \%$ dan $17.64 \%$. Semakin banyak pangan yang dihasilkan dari usahatani dan digunakan untuk konsumsi langsung rumahtangga menunjukkan rumahtangga tani bersifat subsisten dalam maka kegiatan usahatani produksi usahatani. Semakin besar produksi usahatani yang dikonsumsi langsung oleh rumahtangga tani, menurunkan marketed surplus rumahtangga (deRosari et al., 2014; Umboh et al. 2014). Nilai konsumsi pangan yang tidak dibeli oleh rumahtangga di Kecamatan Tompaso Barat dapat dilihat pada Tabel 3. Konsumsi non pangan adalah yang terbesar dari pada konsumsi pangan yang dibeli dan konsumsi pangan yang tidak dibeli. Pengeluaran konsumsi non pangan adalah jenis pengeluaran rumahtangga yang umumnya dibeli dari pasar. Jarang atau bahkan tidak ada rumahtangga tani yang memproduksi barang konsumsi non pangan, sehingga untuk memenuhi kebutuhan non pangan rumahtangga mengandalkan pendapatannya.

Tabel 3. Nilai Konsumsi Pangan Yang Tidak Dibeli di Kecamatan Tompaso Barat

\begin{tabular}{rlcc}
\hline No. & Jenis Pangan & Rata-rata Pengeluaran $(\mathrm{Rp})$ & Persentase $(\%)$ \\
\hline 1. & Beras & 324.360 & 23,62 \\
2. & Umbi & 242.287 & 17,64 \\
3. & Bumbu Makanan & 342.517 & 24,94 \\
4. & Buahan & 240.087 & 17,48 \\
5. & dan lain-lain & 223.850 & 16,30 \\
\hline & Jumlah & 1.373 .101 & 100,00 \\
\hline
\end{tabular}


Tabel 4 Pengeluaran Konsumsi Non Pangan di Kecamatan Tompaso Barat

\begin{tabular}{clcc}
\hline No. & \multicolumn{1}{c}{ Non-Pangan } & $\begin{array}{c}\text { Rata-rata Pengeluaran } \\
(\mathrm{Rp}\end{array}$ & Persentase (\%) \\
\hline 1. & Perumahan, listrik, dan bahan bakar & 4.682233 & 24,11 \\
2. & Barang dan jasa & 3.129683 & 16,11 \\
3. & Biaya pendidikan\&Biaya kesehatan & 3.032713 & 15,62 \\
4. & Pakaian, Alas kaki dan Penutup Kepala & 5.404233 & 27,83 \\
5. & Kredit, pajak, asuransi & 3.166400 & 16,30 \\
\hline & Jumlah & 19415263 & 100,00 \\
\hline
\end{tabular}

Berdasarkan penelitian di Kecamatan Tompaso Barat, diketahui bahwa pengeluaran untuk pakaian, alas kaki, dan penutup kepala merupakan pengeluaran konsumsi non pangan terbesar yakni sebesar $27.83 \%$ diikuti pengeluaran untuk perumahan, listrik, dan bahan bakar sebesar 24.11\%; kredit, pajak, asuransi 16.30\%; barang dan jasa sebesar $16.11 \%$, serta biaya pendidikan dan biaya kesehatan sebesar $15.62 \%$. Hasil penelitian ini sejalan dengan Nainggolan (2015) dan Nicholson (2001). Teori Konsumsi Ernst Engel yang dikatakan bahwa tingkat kesejahteraan dikatakan membaik bila perbandingan pengeluaran untuk konsumsi makanan cenderung sedikit dan sebaliknya pengeluaran untuk non pangan cenderung tinggi. Pengeluaran konsumsi non pangan di Kecamatan Tompaso barat dapat dilihat pada tabel 4 .

\section{KESIMPULAN}

Pengeluaran

konsumsi rumahtangga tani penerima bantuan modal produksi ternak di Kecamatan Tompaso Barat terdiri atas: pengeluaran konsumsi pangan dan non pangan. Pengeluaran konsumsi pangan dibedakan antara pengeluaran konsumsi pangan yang dibeli dan tidak dibeli. Dari ketiga alokasi pengeluaran konsumsi tersebut diketahui bahwa alokasi pengeluaran konsumsi pangan yang dibeli terbesar pada pengeluaran untuk ikan yakni sebesar 28,69 persen, nilai pengeluaran konsumsi pangan yang tidak dibeli pada bumbu makanan (29.94 \%), dan alokasi pengeluaran konsumsi non pangan pada pengeluaran untuk pakaian, alas kaki, dan penutup kepala (27.83\%).

\section{DAFTAR PUSTAKA}

BPS. 2008. Data statistik konsumsi rumahtangga di Indonesia.www.bps.go.id.

BPS. 2017. Persentase Rata-Rata Konsumsi Pangan Di Kabupaten Minahasa. www.bps.go.id.

BPS. 2017. Rata-rata Konsumsi Non Pangan Di Kabupaten Minahasa.www.bps.go.id.

deRosari, B.B., B. M. Sinaga, N. Kusnadi dan M.H. Sawit. 2014. The impact of credit and capital supports on economic behavior of farm households: a household economic 
approach. International Journal of Food and Agricultural Economics 2(3):81-90.

Elly, F.H.,B.M. Sinaga, S.U. Kuntjoro dan N. Kusnadi. 2008.Pengembangan usaha ternak sapi rakyat melalui ontegrasi sapi-tanaman di Sulawesi Utara. Jurnal Litbang Pertanian 27(2):63-68.

Grabiel S.C and C.B Baker.1980.Concept of business and financial risk. American Journal of Agricultural Economics 62 (3): 560-564.

Obara, K., M. McConnell, and J.Dyck. 2010. Japan's Beef Market. Journal of Current Issues in Globalization 5(4):1-52.

Osak R.E.M.F., V.V.J. Panelewen., J Pandey, dan I. D. R. Lumenta. 2014. Pengaruh pendapatan rumahtangga terhadap konsumsi daging (sapi, babi, ayam) di Desa Sea 1 kecamatan Pineleng. Jurnal Zootek 34 (8):522626

Sinaga B.M 2011.Metode Pengumpulan Data. Program Studi Ilmu Ekonomi Pertanian. Fakultas Ilmu Ekonomi dan Manajemen, Sekolah Pascasarjana, Institut Pertanian Bogor, Bogor.

Sihaloho H. 2004.Pemberdayaan Pengusaha Kecil melalui Bantuan Kredit dan Pendampingan.Disertasi. Sekolah Pascasarjana, Institut Pertanian Bogor, Bogor.

Umboh S. J. K., D. B Hakim, B. M Sinaga dan I. K Kariyasa. 2014. Impact of domestic maize price changes on the performance of small scale broiler farming in Indonesia.Jurnal Media Peternakan37(3):198-205. 